\title{
PREDICTING THE PROBABILITY OF WAR DURING BRINKMANSHIP CRISES: THE BEAGLE AND THE MALVINAS CONFLICTS
}

\begin{abstract}
by
Alejandro Luis Corbacho

ABSTRACT

This paper argues that a major cause of war in a brinkmanship crisis is not the misperception of the adversary's response, but rather a situation where leaders are compelled to act because of domestic threats to their power. A comparison of the brinkmanship crises of the Beagle and the Malvinas show that the prospect of war was critically affected by environmental conditions (such as the survival of the regime) under which decision makers operated. These conditions placed strong external constraints on the initiators that affected their judgment and the way they managed the crises. Where the conditions were less severe, as in the Beagle case, the leaders could retreat from the warpath. In the Malvinas case, the leaders confronted a no-win situation and the outcome was war with Great Britain.
\end{abstract}




\section{INTRODUCTION}

Tension among states, a common situation in international politics, sometimes escalates to the level of crisis. These periods of crisis are characterized by uncertainty; some are the prelude to a war, while others are resolved peacefully. Political science theory reflects this uncertainty, especially in the case of the most common type of crisis, brinkmanship, where one state's decision-makers challenge the commitment of another state in order to advance their interests, even at the risk of war. ${ }^{1}$ According to Lebow, "The fundamental assumption about brinkmanship is that initiators expect their adversaries to back away from their commitments when faced with the prospect of war". ${ }^{2}$ More often than not, initiators misperceive the response of their adversary. For this reason, Lebow argues that "misperception is a major cause of war in brinkmanship crisis". $^{3}$

This paper presents a different explanation. It argues that a major cause of war in a brinkmanship crisis is not the misperception of the adversary's response, but rather an objective situation where leaders are compelled to act because of threats to their power.

The study of two recent brinkmanship crises--the Beagle and the Malvinas--will illustrate this explanation. During its most recent authoritarian regime (1976-1983), Argentina experienced two brinkmanship crises. In 1977-78, the country came to the edge of an armed conflict against its neighbor, Chile. The reason for this crisis was the rejection 
by Argentina of the decision of an international court to award to Chile three islands in the southern part of the country. Both countries had not been so close to war since the beginning of the century. The second crisis was Argentina's 1982 war against Great Britain over the Malvinas Islands. In this case the outcome of Argentina's policy was a complete failure, and the price Argentina paid was heavy.

Why did Argentina avoid war against Chile, yet fight against Great Britain? The paper will examine, first, Lebow's influential analysis of brinkmanship's theoretical foundation. I will then study the two cases of brinkmanship, the Beagle and Malvinas crises, in light of a new interpretation. The conclusion will show the shortcomings of the brinkmanship approach when it is limited to cognitive considerations and ignores strategic thinking.

\section{BRINKMANSHIP CRISES: MANIPULATING THE RISKS OF WAR}

Although Lebow notes that "there is no accepted definition of international crisis", ${ }^{4}$ most attempts at definition have some elements in common. Among these elements are the perception of threat, heightened anxieties on the part of decision-makers, the expectation of possible violence, and the belief that important or far-reaching decisions are required and must be made on the basis of incomplete information in a stressful environment. ${ }^{5}$ One type of crisis known as brinkmanship occurs "when a state knowingly challenges an important commitment of another state in the hope of compelling its adversary to back away from his commitment". 
According to Lebow, a brinkmanship challenge is associated to two preconditions: "(1) the existence of serious domestic and international threats that a successful challenge of an adversary's commitment promises to overcome, and (2) perception by the initiator that a vulnerable commitment exists," that is, that the adversary is likely to back away form his commitment. ${ }^{7}$ The defining characteristic of Lebow's brinkmanship crisis is the expectation that the adversary will retreat rather than fight: "our fundamental assumption about brinkmanship is that initiators expect their adversaries to back away from their commitments when faced with the prospect of war". ${ }^{8}$

Although "more often than not that perception is wrong," the outcome of brinkmanship crises is not predetermined. " "The actual management of the crisis [is] allimportant in determining whether or not it is resolved." According to Lebow, "successful mastery of brinkmanship crises...requires that policy reflects a rapid and ongoing learning process in order to expose erroneous perceptions and promote policy more in tune with the existing political realities".

Lebow argues that the outcome of a brinkmanship crisis depends on the answer to two questions: One, how wrong is the initiator in estimating the adversary's resolve? And, two, how much time does the initiator require to recognize his miscalculation and change his policy? $?^{11}$ Thus it is "imperative for initiators to remain sensitive to cues from their environment about the validity of their expectations." His study of several cases leads him to conclude, "when initiators recognized and corrected for initial misjudgments, they usually succeeded in averting war". ${ }^{12} \mathrm{He}$ is not very optimistic about the ability of policymakers to improve their managerial skills during crises, however, for "it is unrealistic to 
think that leaders can be prevailed upon to make their decision-making processes more open, given the threat this can pose to both their power and policy preferences." ${ }^{13}$

The following study of the brinkmanship crises of Beagle and Malvinas will show that domestic political considerations, especially the survival of a regime, are also critical to the decision to initiate a brinkmanship challenge. If, as in the Beagle crisis, policymakers have room to maneuver vis-a-vis domestic social forces, the outcome of the crisis is more uncertain and the actions of external actors become important. Conversely, in the Malvinas case, the military was compelled by domestic political concerns to engage in a brinkmanship challenge regardless its evaluation of the expected behavior of Great Britain or the United States.

\section{THE BEAGLE CHANNEL CRISIS}

In July, 1971, after nearly a century of controversy, the Argentine military government agreed with Chile to have Great Britain arbitrate the Beagle Channel dispute in order to avoid a major conflict in the southernmost part of a shared border of more than 3,000 miles. Chile occupied the three principal islands of the area: Picton, Lennox, and Nueva, and the Hornos Island, as well. According to the terms of the agreement, the British government was restricted to accepting or rejecting the decision of an international court of five jurists. ${ }^{14}$

In May 1977, Great Britain informed the Argentine government of its decision. The arbitration award confirmed the possession by Chile of the islands and (according to 
international law) the adjacent sea area. Because the award was considered a threat to what her strategists considered the vital interests of the nation, the Argentine government decided to reject the award and tried to resume bilateral negotiations with Chile. ${ }^{15}$ When it became clear that the Chileans wanted full acceptance of the resolution, the Argentine position hardened, and Argentina began to challenge the Chilean commitment to defend the territory. Chile's position was that the award was legitimate and all islands, from the Beagle Channel south, belonged to it. Chile agreed to participate in negotiations only over the legal consequences of the award, especially over some controversial issues such as the demarcation of sea limits. ${ }^{16}$

During the Beagle crisis, Argentine policymakers were divided into two groups, hardliners and softliners. ${ }^{17}$ The conflict between Argentina and Chile for the Beagle Channel follows Lebow's description of a brinkmanship crisis originated by an intraelite competition for power: "historically this has often happened when the competition for influence within the policy-making elite reflects a broader social-political struggle." When this occurs, "foreign policy issues may be assessed in terms of how they affect the balance of power between or among the competing factions." ${ }^{18}$ Given the Chilean refusal to enter into new negotiations, the hardliners, pressured for drastic military actions. The softliners, on the contrary, wanted to avoid war and struggled to maintain bilateral negotiations.

On May 31, 1977, after Great Britain's decision in favor of Chile became public, a special commission of Argentine political leaders presented to Argentine President Jorge Videla a demarcation proposal to offer to Chile. ${ }^{19}$ The proposal followed what could be 
considered a moderate line. It was favored by the President, but was rejected by the ruling military Junta. This body was especially influenced by a hardliner, General Osiris Villegas, a well known specialist on geopolitics who acted as the Junta's advisor. Given the Junta's opposition, the proposal of the commission was set aside. ${ }^{20}$

Meanwhile, continuous bilateral diplomatic efforts sought to reach a negotiated solution. Both governments announced that the "channels of communication" remained open. ${ }^{21}$ Unlike Chile, the Argentine government's position was to depart from the legal framework established by the arbitration award and to initiate bilateral negotiations. ${ }^{22}$ On January 25, 1978 the Argentine foreign minister, Admiral Oscar Montes, officially announced the decision of his government to declare Great Britain's award null and void. ${ }^{23}$ The government argued that Great Britain's award contained errors and contradictions. The government's decision, which was adopted with the agreement of the three military services, caused a strongly negative Chilean reaction and brought the two nations to a confrontation. Armed forces were mobilized and an arms race followed. There was a real possibility of open warfare. ${ }^{24}$

Frenzied diplomatic activity occurred alongside the military preparations. In 1977, three missions crossed the Andes in order to negotiate, and there was also a meeting of foreign ministers. ${ }^{25}$ In 1978, the diplomatic agenda of both countries were equally crowded, with two presidential summits, one in the Argentine city of Mendoza (January 19, 1978) and the second in the Chilean city of Puerto Montt (February 20, 1978). There was also one personal envoy from President Pinochet to President Videla, three more special missions, two rounds of meetings of joint commissions (which were created after 
the presidential summit in Puerto Montt), one meeting of secretaries of the armed forces of both countries, one exchange of notes between Presidents Videla and Pinochet, and between foreign ministers as well. ${ }^{26}$

All this diplomatic activity was fruitless, and the crisis continued. Argentina began to exert economic pressure upon Chile. A number of Chilean citizens were expelled, reservists were called up, and blackout drills were conducted in various cities, including Buenos Aires. ${ }^{27}$ The peak of the tension was reached between October and December 1978.

The negotiations by the two joint commissions created during the presidential summits were a failure. The second joint commission ended its meetings in October 1978 after reaching agreement only on minor points. Then the secretaries of the Argentine armed forces traveled to Chile, where they met President Pinochet. During this meeting the idea of mediation was first mentioned. The candidates were numerous: the president of the United States, King Juan Carlos of Spain, a European president, and the Pope. Later, however, the Chilean position changed, and on October 30, 1978, in a further meeting Pinochet adopted a position opposed to mediation. ${ }^{28}$

Meanwhile, Argentina's military machinery was set in motion. Mobilization orders were issued. Argentine army units took positions, and the fleet sailed southbound. Argentine military specialists predicted an 1.8:1 advantage for Argentina in troops, and naval and air force advantages as well. ${ }^{29}$

From the beginning of November, the Argentine Comite Militar (Military Committee) declared itself in permanent session and became the top decision organ on the 
Beagle issue until January $1979 .{ }^{30}$ It was formed by the president, the three members of the Junta, and the secretaries of the three armed forces. ${ }^{31}$ During this period the Junta maintained a hardline position. In October 1978 the Junta rejected any negotiations on sharing the islands, but it agreed to negotiate on sharing maritime spaces. But then many influential officers maintained outside the Comite insisted on a hardline position rejecting all negotiation. This position, was primarily held by the officers in charge of combat units, was the dominant position until October 27, 1978, the Argentine foreign minister, Admiral Oscar Montes resigned. ${ }^{32} \mathrm{He}$ had supported the view, different from that of President Videla, that since bilateral negotiations were deteriorating, Argentina should occupy the islands in the Beagle Channel. According to his opinion, "it did not mean war, however much many in Argentina felt that the occupation of some of the islands did mean war." He added: "this is my personal opinion that was not shared by many people in the Junta, in the Government." ${ }^{13}$ Montes' resignation coincided with a redistribution of ministerial posts among the three service branches. These changes strengthened the softliners.

During this period negotiations with Chile proceeded at the presidential level. In response to a note from President Videla, President Pinochet argued that the continuation of bilateral dialogue would be fruitless and suggested that the use of a mediator would be very helpful. ${ }^{34}$ On November 20 Chilean Foreign Minister Cubillos sent an official diplomatic note to the new Argentine foreign minister, Brigadier Carlos Washington Pastor. The Chilean note proposed that the dispute be submitted to the International Court in The Hague as provided by a 1972 treaty. The Argentine government rejected the 
proposal. The Chilean foreign minister was unofficially informed that Argentina would consider that option as a casus belli. ${ }^{35}$ Cubillos' note also suggested mediation by a friendly government. ${ }^{36}$

The Chilean offer was extensively analyzed by the Comite Militar, the foreign minister, and the Argentine ambassador to Chile, who was present at the meeting. Once the option to present the case to the International Court was rejected, the remaining option--to proceed with mediation--was discussed. Argentine decisionmakers maintained three positions. One position, proposed by members of the foreign ministry, was to continue bilateral negotiations. A second position opposed mediation and favored military escalation. This group was formed by the hawks of the army and navy, especially the commanders of the army corps (Generals Menendez, Suarez Mason, and Vaquero) and General Osiris Villegas. The third position was to accept mediation under conditions that protected the Argentine principle of oceanic separation (Argentina to the Atlantic and Chile to the Pacific). The president and the Junta supported this position. ${ }^{37}$ After long discussion, a decision was reached combining elements of the first and third positions. The Comite Militar accepted mediation under the conditions that both countries define precisely their differences and both agree to establish some criteria to be used to reach a pacific solution. ${ }^{38}$

The two foreign ministers agreed to meet on December 12 in Buenos Aires. Informally, they had agreed to mediation; now in the meeting they had to decide, formally, who would be asked to mediate ${ }^{39}$ Argentine Minister Pastor asserted that the only candidate acceptable for his government was the Pope. The Chilean minister agreed. 
Later the same day, the Chilean minister received a phone call from Minister Pastor, informing him that neither President Videla nor Minister Pastor had been authorized by the Junta to sign the mediation agreement. ${ }^{40}$ This occurred because there was no agreement within the Comite Militar and between it and the Executive. ${ }^{41}$ According to Argentine sources, the reason for the rejection was that there was no agreement between the ministers of both countries about the scope of the mediation. Argentina wanted a precise definition of the range of the mediation. Chile expected to present the mediator a lessdefined agenda.

The crisis escalated. Argentina announced that due to Chile's intransigence, the country had decided to use force. ${ }^{42}$ After the failure of the foreign ministers' meeting, the Comite Militar began to operate permanently in the air force command building. The hardliners assumed charge of the situation; President Videla and the foreign minister were not invited to the Comite meetings. The commander in chief of the army, General Viola, pressed for fixing a date to proceed with military action. His position was based on strong pressures from within the army (on December 14, during a tumultuous meeting, the high command of the army pressured General Viola to commit to military action). Under this pressure, Viola participated later in the meetings of the Comite Militar, although there is evidence that his personal position was conciliatory. ${ }^{43}$ During the meeting, it is said, he first tried to gain time while saying that Argentina would have to wait for the United States "to develop its strategy" ( $\underline{\text { sic) }}$, but he was overcome by the hardliners. ${ }^{44}$ Besides taking the role of middle-liners, the commanders of the navy, Admiral Armando Lambruschini, and of the air force, Brigadier Orlando Agosti, were not enthusiastic about 
military operations. Both argued that the time for such a drastic measure had not yet arrived. $^{45}$ The newspaper Clarin explained some years later that such caution was based, in part, on military concerns. In order to achieve a victory, certain objectives had to be reached before the seventh day after the attack. Some military leaders considered this not enough time due to the difficulty involved in transportation through the passes over the Andean Mountains. ${ }^{46}$

Despite these concerns, the Comite decided on armed action, and on December 14, President Videla explained to Papal Nuncio Pio Laghi that he had given orders to invade the islands on either the 21 st or 22 nd of December. He had little choice; otherwise he would have been removed. $^{47}$ The issue was rapidly heading toward a military confrontation.

On December 19, Chilean Foreign Minister Cubillos again sent a note to the Argentine government proposing Vatican mediation. Again, the Argentine government rejected it because the proposal did not satisfy Argentina's minimal expectations. The disagreement about the scope of the mediation continued, and Argentina sent a naval squadron to the area in conflict and Chile did the same. ${ }^{48}$ Luckily, due to bad weather the two naval squadrons never met. ${ }^{49}$

Meanwhile, the Pope, alarmed by the situation, decided to act personally and informed both governments that he was sending his personal envoy to both capitals. ${ }^{50}$ Six hours before the fixed hour for the initiation of hostilities on December 22, the military operation (Operation Soberania) was called off. The Pope's offer of "good offices" had the effect of suddenly changing the conditions of the internal struggle within the Comite 
Militar. Specifically, the Pope's announcement made the middleliners change their position to the acceptance of mediation and immediate cease of military operation. ${ }^{51}$ The appearance of the Pope had been effective, and the hardliners within the Argentine government had to back down. ${ }^{52}$

The role of third parties helped considerably to resolve the dispute between Chile and Argentina. Vatican diplomacy was decisive in avoiding the military confrontation because it combined significant moral influence over the parties with a subtle yet firm and pragmatic diplomacy aimed at bringing both parties closer together. ${ }^{53}$ Moreover, the Pope was not alone in his concerns. As the tension increased, the international community expressed alarm. ${ }^{54}$ The activity of the American and Vatican ambassadors in both countries was significant, with both urging a negotiated solution. ${ }^{55}$ The decision of the Pope to send his personal delegate gave President Videla and his government a diplomatic exit from its hardline course.

The role of the United States in this crisis should also be highlighted. In addition to the actions of the American ambassadors in Chile and Argentina, the decisions taken by President Carter were important. The United States made it absolutely clear to Argentina that any military action would not be accepted. ${ }^{56}$ However, the U.S. government understood the influence of the Vatican; accordingly, United States diplomacy focused upon encouraging the Pope's intervention. ${ }^{57}$

On January 8, 1979, the presidents of Argentina and Chile met in Montevideo, where in the presence of the Vatican envoy they signed a non-aggression pact and agreed to a compromise that returned the military situation to that of $1977 .^{58}$ 


\section{THE CRISIS OF THE MALVINAS, 1981-1982}

In an article originally published in 1983, Lebow explained the causes of the war in the South Atlantic in terms of a set of mutually reinforcing misperceptions. On the one hand, "the belief in London that Argentina would not invade the [Malvinas] Islands;" and on the other hand, "the expectations in Buenos Aires that Britain would accommodate itself to a military takeover of the islands." ${ }^{59}$ Moreover, Argentines also miscalculated the United States' reaction to the overtake. They were confident that the country would acknowledge the Argentine action, or at least remain neutral. ${ }^{60}$ Clearly, "Argentina's leaders ... had no desire to provoke a war with Great Britain," but their error was that "like many initiators of brinkmanship crises, they miscalculated their adversary's response, an error that resulted in war." ${ }^{61}$

Other scholars agree with this argument, stating that the misperception had several pernicious effects, the most important of which was that Argentine planning was only for a short occupation and not for war. ${ }^{62}$ It is generally argued that both this misperception and the clear military inferiority of the Argentine forces produced the military defeat and the consequent breakdown of Argentina's military regime. ${ }^{63}$

It follows from this argument that had the Argentines understood the British resolve to defend the islands, they would have restrained themselves from proceeding with military action. But, according to Lebow, the Junta's miscalculations "were rationalizations for a policy to which the generals were committed." ${ }^{64}$ In this case, the 
rationalizations "constituted a psychological shield behind which the Junta could protect itself from threatening realities that lay beyond the barrack walls.," ${ }^{65}$ Here Lebow underscores a problem with his general brinkmanship model. The Argentine misperception about British resolve, is also part of a rationalization by the actors who had to convince themselves about the conditions needed to succeed. "Galtieri and his colleagues, compelled for internal political reasons to go forward with the invasion, sought to insulate themselves from information that suggested their policy could lead to war.".66 Once the decision was taken, the military rationalized the probability of success, which in turn produced their cognitive closure. ${ }^{67}$ The dynamic of decision-making was of the groupthink type. ${ }^{68}$ The Malvinas crisis ended in war not because of the initiators' misperceptions about Great Britain's resolve, but, rather, because of the decision of the Junta to risk a "regime-rescue" operation through brinkmanship. Once committed, the Argentine military could not back down. ${ }^{69}$

According to Lebow, Argentine policy toward the Malvinas was decisively influenced by domestic concerns. The Junta's motivation was based on "the need to do something to restore its faltering legitimacy". ${ }^{70}$ Levy and Vakili have demonstrated that the military regime aimed to use foreign policy as a diversionary action in order to improve its domestic political support. Their argument is that authoritarian regimes "faced with a narrowing base of public support, and economic crisis ... often perceive a third option-diversionary behavior. If the target is carefully selected, diversionary actions can work both to unify the regime internally around a new mission and to increase its domestic political support (or at least to buy some additional time) through appeals to 
patriotic symbols of nationalism."

Beginning around 1980, the failure of the economic program and the successful completion of the suppression of terrorism left the military regime without a shared sense of mission and with serious disagreements over economic and social policy and how best to secure the institutional interests of the military. The regime had significant divisions, which facilitated the formation of a domestic civilian opposition. ${ }^{72}$ Pressures for a political opening increased..$^{73}$ In the absence of viable alternatives, internal bargaining within the military regime led to the decision to invade the Malvinas as a means of reestablishing the corporate unity of the military around the Malvinas issue and at the same time establishing the regime's legitimacy with society. ${ }^{74}$ Freedman and GambaStonehouse assess the situation of the regime in the following terms: "There were powerful domestic and international reasons for action. The Junta's inheritance was uncomfortable. Its predecessors had made themselves unpopular through severe political repression combined with the steady deterioration of the economy ... The [Malvinas] issue was coming to be seen as central to Argentina's future position in the South Atlantic, as well as being the only major foreign policy issue upon which it could act in 1982."

Since 1833, Argentina and Great Britain had been negotiating over the sovereignty of the Malvinas Islands. During the 1960s and 1970s some very slow progress was made, but negotiations ended in a deadlock at the end of the 1970s. In March 1981 Argentina's new president, Roberto Viola, was "elected" by the Junta to serve for a period of 3 years. The ensuing months were marked by continuous struggle between the Executive and the 
Junta. General Viola intended to liberalize the regime, but important sectors of the military were strongly opposed to such a move. ${ }^{76}$ The situation did not last long. In December 1981, Viola was removed and General Leopoldo Galtieri became the new president and also the commander of the army. With Galtieri serving as both president and commander-in-chief of the army, the structure of power was altered, violating the 1978 agreement among the Junta members which required the commander-in-chief of the army to retire from military duty in order to serve as president. However, the price for agreeing to this change by the navy was the approval by the army of a military operation against the Malvinas. $^{77}$

In January 1982, President Galtieri began to focus on the country's foreign policy. The president paid much attention in the appointment of a new foreign minister. He selected Nicanor Costa Mendez, a person with experience with the Malvinas as foreign minister of a past military regime. He was considered a hardliner by the Junta. ${ }^{78}$

In order to improve its image and position, domestic and internationally, the government mounted a new diplomatic campaign over the Beagle Channel, and in February it gave hints of pending military involvement in Central America to earn U.S. support. This was soon followed by a diplomatic offensive against Great Britain. In this offensive, Galtieri demanded an acknowledgement of Argentina's sovereignty over the Malvinas Islands. The Malvinas issue was promising in terms of public support, and it gained increasing primacy on the Junta's diplomatic agenda. The decision to focus on the Malvinas also could be easily justified on geopolitical considerations. For the Argentine military, "the basic geopolitical rationale for recovering the Malvinas in April 1982 met at 
a point in time with the impending collapse of the Argentine military government, the psychological need to do something about the islands before the one hundred fiftieth anniversary of their loss, and the growing realization of the implications of the Antarctic Treaty revision in 1991." ${ }^{79}$

Two days before Galtieri became president on December 22, 1981, the chief of naval operations, Vice-Admiral Juan José Lombardo, had drafted the invasion plan for the second half of $1982 .{ }^{80}$ Unlike the Beagle crisis, preparations for the attack were kept in absolute secrecy. The operation was designed to be bloodless in order to limit the possibility of a British reaction and to help in creating a better atmosphere for negotiations. $^{81}$ For this reason, it depended on surprise, and it would be fatally undermined if there were any British reinforcements of the islands' garrison. Thus only a small group knew of the plan. At the beginning of 1982, "it is believed that...no more than nine individuals knew of any firm intention by the junta to invade." ${ }^{82}$ On December 29 , 1981, Galtieri and Anaya informed Brigadier Basilio Lami Dozo, commander-in-chief of the air force, of their intention to capture the islands. He accepted their proposal at once. $^{83}$ The plan was so secret that "even Foreign Minister Costa Mendez was unaware of the planning exercise while he prepared his diplomatic initiative in January. He knew only that the Junta intended to increase tension if the British failed to offer serious concessions." ${ }^{84}$ It was only in early February that Galtieri was authorized by the Junta to inform Costa Mendez about the military planning. ${ }^{85}$ In this way, unlike the Beagle crisis, decisions and military preparations were kept in absolute secret so public debates and international pressure were avoided. The hardliners sought to present the world with a 
fait accompli.

During February, a New York conference between Argentine and British representatives failed. Domestic pressures for a more decisive action by the military regime were therefore reinforced by the lack of progress in negotiations. ${ }^{86}$ The British position to accept Argentina's proposal to establish a negotiating commission was assessed in Buenos Aires as mere procrastination. Britain had shown no indication that she intended to accept Argentine claims. ${ }^{87}$

At about the same time, the United States Assistant Secretary of State for Latin American Affairs, Thomas Enders, visited Argentina. ${ }^{88}$ During a meal offered by the United State ambassador, Costa Mendez outlined the next steps of Argentine diplomacy to Mr. Enders. It is reported that the Argentine foreign minister informed the American official that "Argentina planned a vast diplomatic offensive that would culminate in the UN General Assembly in November of that year." Further, "he left no doubt that the tension would increase. (He was thinking of moving by stages if Britain persisted in its delaying policy)." 8

An unexpected event produced a sudden changed in plans. In March, the situation escalated because of an incident involving Argentine workers in the South Georgia Islands. These islands were controlled from the Malvinas and were the home of a British scientific station. A group of Argentine workers disembarked in order to scrap an abandoned whale factory. ${ }^{90}$ They raised the Argentine flag, and the British ordered them to reembark immediately. To back its demand, the British government sent a patrol ship, the H.M.S. Endurance. 
Argentina reacted by sending two warships to the area, and the crisis escalated. Afraid that the British might reinforce the island, the Argentine military decided to invade immediately. As an Argentine military officer later commented, "the unexpected British reaction [to the Argentine workers' presence in the South Georgias]... triggered the crisis and forced the Argentines to advance forty days earlier the military recuperation of the Malvinas Islands. ${ }^{111}$ On April 2, 1982, Argentine Special Forces occupied the islands. Lebow states, "in weighing their decision, it seems likely that Galtieri and his colleagues in the Junta were in the end swayed by the considerations that backing down entailed near certain political disaster whereas invasion, if it did not lead to war, held out the prospect of substantial gains for little cost." ${ }^{12}$

Unlike the Beagle dispute, the case of the Malvinas found key decision-makers united in their goal to recuperate the islands: "when the Junta asked the opinion of the Chiefs of Staff of the three armed forces on 26 March whether or not they could mount an intervention immediately, the reply was in all cases affirmative. ${ }^{13}$ As commander-inchief of the army, General Galtieri had created a force very loyal to him by retiring all the high-ranking officers in possible opposition. ${ }^{94}$ When informed of the decision during the same meeting on March 26th, even the foreign minister, Nicanor Costa Mendez, categorically replied to the Junta: "if you have decided to go ahead with the operation, let me advise you to do it as soon as possible...there is the possibility that the information might leak; if so, the possibility of a bloodless landing would be reduced.".95

During the weeks previous to the Argentine operation, both the United States and Great Britain were well aware of the Argentine preparations. ${ }^{96}$ The British prime 
minister's "first response to the intelligence she received on the evening of 31 March was to send an urgent message to President Reagan warning of what was about to happen, insisting that Britain would not acquiesce in an occupation, and asking the President to contact Galtieri immediately for an assurance that he would not authorize such a thing."."97 In response the American government tried on three opportunities to defuse the crisis by offering the country good offices to the Argentines. ${ }^{98}$

On March 30, after the incident on the South Georgian islands, the American ambassador in Buenos Aires, Harry Schlaudeman, offered during a meeting with the Argentine foreign minister the good offices of his country to solve the problem. The ambassador was unable to answer Costa Mendez's response that Argentina wanted an assurance of an agreement on the Malvinas. ${ }^{99}$ The second offer came on April 1, when Assistant Secretary of State Thomas Enders arranged a meeting between Esteban Takacs, the Argentine ambassador in the United States, and Secretary of State Alexander Haig. On this occasion, the secretary of state offered the personal intervention of Vice-President George Bush as mediator. When Takacs later informed Costa Mendez about the proposal, he received as his sole answer: "I take note." ${ }^{100}$

Finally, President Reagan telephoned General Galtieri hours before the invasion, but Galtieri waited until the invasion had begun to answer the call. President Reagan tried to convince President Galtieri to stop any action that might imply the use of force. Again, the president of the United States offered to send Vice-President Bush to Buenos Aires. President Reagan added that Ambassador Kirkpatrick would also assist the parties in the United Nations. ${ }^{101}$ President Galtieri again declined to accept the offer. According to the 
reconstructed dialogue, when confronted with the Argentine refusal, Mr. Reagan began to add pressure: "Mr. President [Galtieri] I believe that it is my obligation to bring to your notice that Great Britain is ready to respond militarily to an Argentine landing. The United Kingdom has made this known to me. Furthermore, Mrs. Thatcher, a friend of mine, is a very determined woman and she would have no other alternative than to make a military response." When all other efforts to convince the Argentine president failed, $\mathrm{Mr}$ Reagan added:

I understand from your words, Mr. President [Galtieri], that Argentina reserves the right to use force. I want to make clear that the relationship between your country and mine will suffer gravely. American and worldwide public opinion will take a negative attitude to an Argentine use of force. Besides, the effort I have made to restore our relationship will be severely affected. Great Britain, Mr. President, is a very close friend of the United States and one will see the new relationship that Washington has with Argentina-achieved in full view of American public opinion and after a long effort- irremediably prejudiced. ${ }^{102}$

The United States's intervention in this case is strongly criticized by American and British scholars. ${ }^{103}$ One of the reasons for the failure of the United States to restrain Argentina is attributed to the relationship established between the Reagan administration and the Argentine military. After Feldman traces the path of negotiations which involved the United States, he concludes that

not only was the U.S. unable to deter Argentina from its attempt to regain the Malvinas, or able to persuade them to accept compromise solutions to the conflict, but the very efforts used by the Reagan administration to enlist Argentine support for U.S. hemispheric security efforts actually enhanced chances for war by nurturing in Argentina an exaggerated sense of its own strategic importance.

The Argentine government seriously misperceived that the United States government 
would support Argentina, or at least, remain neutral. ${ }^{105}$ But on three different occasions, the United States sent clear messages to the Argentine government. What is clearer than a personal phone call from the president, himself, to General Galtieri? The question is why did the messages fail to achieve their purpose? One explanation is that if the occupation was a symbolic gesture to force Britain to negotiate seriously, then the opposition of the United States to a military action was not going to have any effect on the Argentine actions. $^{106}$

The Argentine government had no incentive to oppose the decision to invade. It has to be remembered that the political support to Galtieri depended upon the operation. Moreover, the existence of the entire regime was believed to rest on the recovery of the islands. Under such circumstances, it is improbable that President Galtieri would have opened a door to a process of negotiation that would constitute backing away from the islands. The navy, and specially Admiral Anaya, were eager to go on with the operation because of the gains expected from its success. The result was a unified coalition to carry on the military operations. This situation contrasts sharply with the governmental factionalism during the Beagle crisis, where both the Argentine president and the foreign minister after Montes's removal favored a peaceful resolution of the crisis, and where some members of the Junta were dubious about the wisdom of conducting military operations against Chile.

In the end, the tragedy was that "the generals were caught between the military facts, which dictated a settlement, and the political facts at home, which indicated that...their tenure as Argentina's leaders was unlikely to survive any settlement they had 
any chance of reaching." ${ }^{107}$ As a consequence, the war in the South Atlantic was not the product of faulty cognition, but a conscious choice by the Argentine military leaders that found no alternative to their survival other than to challenge Britain. ${ }^{108}$

\section{CONCLUSION}

Most analysts are surprised by the fact that Argentina did not fight against the weaker of its adversaries (Chile), but instead fought one much more powerful, Great Britain, which, in spite of being far away, was considered a traditional friend of Argentina. ${ }^{109}$ Lebow's answer to this paradox is that "in practice, relative military advantage, while it is an important consideration, is rarely the determining factor in foreign policy challenges." ${ }^{110}$ Elsewhere Lebow notes that "what counts is the perception by the initiator that...a vulnerable commitment exists." ${ }^{111}$

As we have seen from the two case studies, the Beagle and Malvinas crises, the prospect of war was critically affected not by misperceptions about the existence of an adversary's vulnerable commitment, but mainly by environmental conditions (such as the survival of the regime) under which the decision makers operated. These conditions placed strong external constrains on the initiators that affected their judgment and the way they managed the crises. The conclusion is that when domestic threats to the initiator are severe, military considerations are not critical to decisionmaking.

Thus Lebow's theoretical formulations do not predict the outcome of brinkmanship crises. He asserts that initiators' misperceptions lead to war on many 
occasions but that if the initiator quickly recognizes his mistake and responds correctly to the situation, the chances of overcoming the crisis without war increase dramatically. Although Lebow remains skeptical of this retreat scenario, this study has suggested that there are brinkmanship cases like the Malvinas crisis where leaders confront domestic threats that appear as no-win situations. They are compelled to create a crisis, not because of misperceptions about the adversary but, rather, because of domestic pressures. Even if they recognize their misperception, they cannot back down.

The Malvinas case is similar to those of Korea (1950) and India (1962). According to Lebow, "Truman and Nehru faced what appeared to be no-win situation. Public opinion in their respective countries force them to commit themselves to foreign policies that increasingly appeared to court war with China... Caution on the other hand was certain to precipitate their political demise." And then, Lebow adds, "Truman and Nehru attempted to escape from this dilemma by convincing themselves that they could in fact pursue confrontatory policies without provoking war with China." ${ }^{112}$ It is my opinion that Lebow should have written: "Given their pressing domestic problems, they decided to confront the risk of a brinkmanship, while hoping that China would back down." First came the brinkmanship decision, then the rationalizations that served as justifications for the decision.

Conversely, in the Beagle crisis the outcome was more difficult to predict, given the struggle between factions. On that occasion, the Pope's intervention was an external factor that helped to shift the balance in favor of the antiwar faction. Unlike the Malvinas crisis, in the Beagle crisis the military could back down without losing face or confronting 
their dismissal from power. In this case, where the confrontation was intraelite, the regime had room for a diplomatic retreat.

In short, when an adversary is resolved to defend his commitment, and when the domestic conditions that the initiators confront are critical for their survival, it is possible to predict the outcome of a brinkmanship crisis. In those cases the outcome is war. 
${ }^{1}$ See Lebow 1981, 267-68.

${ }^{2}$ Lebow 1981, 91.

${ }^{3}$ Lebow 1981, 101.

${ }^{4} 1981,7$.

${ }^{5}$ Lebow 1981, 9. He proposes a definition of international crisis in terms of three aspects of perception: (1) policy-makers perceive that the action or threatened action of another international actor seriously impairs concrete national interests, the country's bargaining reputation, or their own ability to remain in power; (2) policy-makers perceive that any actions on their part designed to counter this threat will raise a significant prospect of war; and (3) policy-makers perceive themselves to be acting under time constraints (1981, 1012).

${ }^{6}$ Lebow 1981, 57. He identifies two other types of crises: justification of hostility and spin-off. The latter occurs when extraordinary actions on the part of the belligerent, designed to advance the initiators' interests, provoke confrontations with third parties $(1981,41)$. In the former, the leaders of the initiating nation have made a decision for war before the crisis commences (Lebow 1981, 25).

${ }^{7}$ Lebow 1981, 61.

${ }^{8}$ Lebow 1981, 91.

${ }^{9}$ Lebow 1981, 97.

${ }^{10}$ Lebow 1981, 270, 271.

${ }^{11}$ Lebow1981, 267.

${ }^{12}$ Lebow 1981, 335.

${ }_{14}^{13}$ Lebow 1981, 305.

${ }_{15}^{14}$ Garret 1985, 90.

${ }^{15}$ The Argentine foregn minister at that time expressed the idea "...no commitment obliges a country to comply with that which affeets its vital interests or that which damages rights of sovereignty" (Princen 105). The award was perceived as especially threatening the so-called bi-oceanic principle which maintained that Argentina has to control the Atlantic waters while Chile the Pacific. Further, "although the size of the islands...averages only slightly more than 40 square miles, possession of the islands establishes control over an additional 30,000 square maritime miles, if one assumes the 200-mile limit." Argentina was also concerned about control of Patagonia, the southern part of the country, where large numbers of Chileans had settled. Argentines have always been sensitive to Chilean presence in the area Another reason for the intransigence of the parties involved competing claims in Antarctica (Garet 82). Finally, reinforcing these objections was the idea that Argentina interpreted the award as a symbol of the continuing teritorial amputation that, according to Argentine history textbooks, the country has suffered since its independence in 1816 (Escude 1990).

${ }^{16}$ Russell 1990, 38.

${ }^{17} \mathrm{~T}$ ypically, hardliners advocate firmness in crises, and they are wary of accommodative moves, fearing that will be interpreted as weakness. Conversely, softliners are typically more fearful that events will get out of control. They advocate a more accommodative policy. Glenn Snyder and Paul Diesing, Conflict Among Nations: Bargaining, Decision Making, and System Structure in International Crises, (Princeton, NJ: Princeton University Press, 1977) 298-309.

${ }^{18}$ For instance, intraelite competition was a primary cause of the brinkmanship crises of Fashoda (1898), Korea (1903-1904), and the Sino-Indian (1962) (Lebow 1981, 71).

${ }^{19}$ The commission operated in the Fordign Ministry and was composed of representatives of the three branches of the armed forces, ministries of economy and fordign relations, joint chiefs of staff, and the secretary of public information (Russell 37).

${ }^{20}$ Lanus 518; Russell 37. 
${ }^{21}$ Garrett 97.

${ }^{22}$ Princen 105.

${ }^{23}$ Princen 108.

${ }^{24}$ Argentine arms imports rose steeply after the arbitration award. Orders were placed for 4 frigates, 4 destroyers, 6 corvettes, 6 submarines, tanks, and 26 jet planes. Chile doubled its military expenditure from 1977 to 1980. It imported a number of major weapons: 95 aircraft, 30 helicopters, 16 missile armed fast patrol boats, 2 submarines, missiles, etc. (SIPRI Yearbook 1982, 410). According to Princen, as early as September 1977, Argentina began to mobilize naval units, and by December its army troops had been deployed to the South (106).

${ }^{25}$ Russell 36-40.

${ }^{26}$ Russell 40-52.

${ }^{27}$ Princen 112-13.

${ }^{28}$ Russell 44-45.

29 "Como se evito la guera con Chile" (Buenos Aires: Clann, August 19, 1990 p.11). "Historia secreta de la

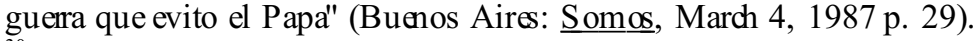

${ }^{30}$ Russell 45-46.

${ }_{32}^{31}$ Later, in mid-November, two more members were added, both from the army's staff.

${ }^{32}$ Russell 46. For example, the army corps commanders had a strong gravitation in power schema of the military regime. The corp commanders were responsible for a military zone (which averaged five or four provinces) in the framework of the antisubversive struggle. They also exerted "de facto power over the judiciary, as well as influence[d] policy making at both provincial and national levels" (Andres Fontana, Political Decision Making by a Military Corporation: Argentina 1976-1983, Ph.D. dissertation, University of Texas at Austin, 1987 p. 100).

${ }^{33}$ Princen 113. Admiral Montes was appointed foreign minister while Admiral Massera was a member of the Junta. Massera favored a hard position against Chile. However, after the replacement of Massera by the more moderate Admiral Lambruschini and the reorganization of the government, Montes' position became more of an irritant to President Vidda.

${ }_{35}^{34}$ Somos 1984, 32-33;

${ }_{35}$ Princen 115; Lanus 525-26. It was clear to the Argentine government that the International Court would sustain the award favorable to Chile.

${ }^{36}$ See Princen 115.

${ }^{37}$ Russell 47-48.

${ }^{38}$ Russell 48-49.

${ }^{39}$ Princen 115.

${ }^{40}$ Princen 117.

${ }^{41}$ Russell 50. In this regard, the Chilean minister commented: "I have the feeling that I am not talking with

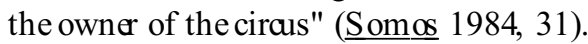

${ }^{42}$ Russell 49.The Argentine military operation was code named "Operation Sovereignty." The date for the assault was fixed for December 21 or 22. The military planned to occupy two islands (Nueva and Hornos), wait for the Chilean reaction and then reply.(Russell 50) In this way the plan resembled that of the Malvinas invasion in 1982 (Operation Blue). For a more detailed explanation about the Argentine military planning see Somos March 4, 1987, 28-29.

${ }^{43}$ Somos 1984, 31.

${ }^{44}$ According to $\underline{\text { Somos}}$, Viola later confessed his duality: "I am a 'hard' in the Junta and a 'soff' in the Army. I always lose" (1984, 31; my translation).

${ }^{45}$ Russell 50.

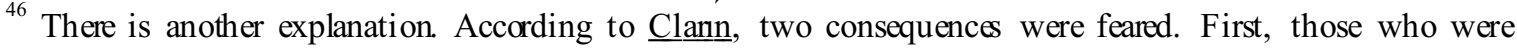
dubious feared a possible regionalization of the conflict. Second, as a consequence, the conflict could acquire 
great power proportions. In the first case decisionmakers speculated that Peru, Bolivia, Ecuador, and Brazil might intervene. Then the great powers could take sides. In this case, the resolution of the conflict would depend not on the combatants, but on the countries that supplied the weapons (11).

${ }^{47}$ Princen 118.

${ }^{48}$ Russell 52. At the same time Argentina had drafted a declaration of war (Princen 119).

${ }^{49}$ Garret 96.

${ }^{50}$ Princen 119, 130. The Vatican believed incorrectly that two Catholic countries would not initiate a fight during the Christmas holidays. Only urgent calls from its representatives on the spot, and messages from the American government, convinced the Pope to act immediately (Clann 11; Russell 51).

${ }^{51}$ Clann states that on Friday December 22, 1978 the Comite Militar held an urgent meeting. The Foregn Minister was also present. Deliberations were short. The predominant opinion to accept mediation if it was possible. Later, the president and the junta deliberated alone for some minutes. When the forign minister was called, he was informed that the mediation was accepted (11).

${ }^{52}$ Russell 52.

${ }^{53}$ Wilhelmy 162.

${ }^{54}$ For instance Brazil offered to mediate and the president of the United States, Jimmy Carter, also offered to aid in the search for a mediator.

${ }_{55}$ Another key figure in the process for pressing for the Vatican intervention was Cardinal Primatesta, the Argentine bishop of Cordoba. During the month of December, he had personal access to the Pope (Armando Amuchastegui Astrada, Argentina-Chile. Controversia y mediacion [Buenos Aires: Imprenta de los Buenos Ayres, 1980] 162).

${ }_{57}^{56}$ For an account of the U.S. diplomatic activity, see Russell 50-51; Princen 188; and Lanus 527-28.

${ }^{57}$ Princen 126; Russell 51. A crucial factor was the role that played by the national church. As Princen says: "on both sides of the Andes, the local churches took an active role in promoting a resolution of the dispute" (127). He adds, "high levd officials of the Church on both sides of the Andes conferred with each other and encouraged support at the parish levd" (128). This factor was critical to reinforcing the moral weight of a papal mediation.

${ }^{58}$ The dispute was finally solved in 1985 , when both countries accepted the Vatican proposal and signed a Treaty of Peace and Friendship. See Garret; Russell 53-58.

${ }^{59}$ Lebow $1985,89$.

${ }^{60}$ Levy and Vakili 27; Lawrence Freedman and Virginia Gamba-Stonchouse, Signals of War. The Falklands Conflict of 1982 (Princeton, NJ: Princeton University Press, 1991) 80-81; Lebow 1985, 112-14.

${ }^{61}$ Lebow 1985, 119-20.

${ }^{62}$ Leonard Wainstein, "Reffexion on a Small War," Conflict 6:2 (1985) 103. Argentine actors corroborate this assumption. See, for example, Martin Middlebrook, TheFight for the 'Malvinas.' The Argentine Forces in the Falklands War. London: Penguin Books, 1989) especially 55-56, 66, and 71.

${ }^{63}$ See "The Falklands/Malvinas conflict--a spur to arms build-ups," in World Armaments and Disarmament (New York: SIPRI Yearbook, 1983) 475-76.

${ }^{64}$ The miscalculations were lack of British resolve, the difficulty of recapturing the Malvinas, expectations of U.S. neutrality, and differing cognitive conceptions of the controversy (Lebow 1985, 119).

${ }^{65}$ Lebow 1985, 119.

${ }^{66}$ Lebow 1985, 119.

${ }^{67}$ Lebow 1981, 105.

68 "Groupthink is a term to refer to a mode of thinking that people engage in when they are deeply involved in a cohesive in-group, when the member's striving for unanimity overide their motivation to realistically appraise alternative courses of action," Irving L. Janis, Groupthink. Psychological Studies of Policy Decisions and Fiascoes, 2d ed. (Boston: Houghton Mifflin, 1982) 9. In this case, "the central features of groupthink are 
signs of high cohesiveness and an accompanying concurrence-seeking tendency that interfere with critical thinking" (idem). Under such ciramstances, a failure to appraise a broader number of alternatives defines more precisely groupthink as the appearance of a premature consensus. Thus, "the outcome of groupthink decisions deserved to be fiascoes because of the grossly inadequate way the policy makers carried out their decisionmaking tasks," Philip Tetlock, "Psychological Research on Foreign Policy. A methodological overview," in L. Wheder and Ph. Shaver (eds.), Review of Personality and Social Psychology vol. 4 (Beverly Hills, CA: Sage Publications, 1983) 64.

${ }_{70}^{69}$ Once the challenge began, the only favorable solution to the military was a British retreat.

${ }^{70}$ Lebow 1985, 123-24. He adds, "the [Malvinas] crisis is by no means unique in the extent to which domestic political concerns, often short term in nature, shaped foreign policy decisions, including those entailing high risks" $(1985,124)$.

${ }^{71}$ The other two options are to liberalize the regimen or to clamp down through further repression (Levy and Vakili 16).

${ }_{73}^{72}$ Levy and Vakili, 29.

${ }_{74}^{73}$ Floria and Garcia Belsunce 256-59.

${ }^{74}$ Levi and Vakili 29.

${ }^{75}$ Freedman and Gamba-Stonehouse 4. It is no wonder that an Argentine military officer claimed some years later: "it is difficult to find in military history a similar example where a country had decided to take such a risk; and at the same time, where its leaders have been so inflexible negotiators and while being under such disadvantaged conditions," Francisco Cervo, "Los factores hịstoricos y geograficos" in F. R. Aguiar, et al. Operaciones terrestres en las Islas Malvinas (Buenos Aires: Ciraulo Militar, 1985) 46-47; my translation.

${ }^{76}$ Internal political opposition began to form when the most important political parties for the first time gathered in order to present a unified front of opposition, the Multipartidaria.

${ }^{77}$ Hastings and Jenkins 46; see also, O. R. Cardoso, R. Kirshbaum, and E. Van Der Kooy, Malvinas. La trama secreta (Buenos Aires: Sudamericana/Planeta, 1983) 21.

${ }^{78}$ Cardoso et al. 1983, 3,5-36. He had been foreign minister under President Juan Carlos Ongania during the regime of the "Revolucion Argentina" until 1968. "The new President [Galtieri]... made contact with Nicanor Costa Mendez. This was a man with credentials compatible with Galtieri's plan and with nostalgia for the [Malvinas]," O. R. Cardoso et al., Falklands--The Secret Plot (Surey, UK: Preston Editions, 1987) 22.

Freedman and Gamba-Stonehouse characterize Costa Mendez as having "long experience with the [Malvinas] issue, having been closely involved in the early Anglo-Argentine talks of 1966-8" (3).

${ }^{79}$ Jack Child, Geopolitics and Conflict in South America._Quarels Among Neighbors. (New York: Praeger, 1985) 121.

${ }^{80}$ Cardoso et al. 1983, 20. An earlier invasion plan had been prepared in detail by the navy commander, Admiral Jorge Anaya, when he was commander of the SeaFleet in 1977. Lombardo revised this strategy.

${ }^{81}$ For the Argentines, the military operation against the islands was considered, fundamentally, a political act and not a war, act. It basically aimed to impose on Great Britain serious negotiations upon the issue of sovereignty (Félix Roberto Aguiar, "La crisis y la guera" in F. R. Aguiar, et al., Operaciones terrestres en las Islas Malvinas [Buenos Aires: Ciralo Militar, 1985] 18). After the seizure of the islands, the plan placed scant importance on their defense. The expectation was that the occupation would put in motion diplomatic negotiations (idem. 22).

${ }^{82}$ Hastings and Jenkins 48 . The military planning was produced by an ad hoc working committee (Comite de Trabajo) formed by the General Osvaldo Garcia, Vice-Admiral Juan J. Lombardo and Brigadier Mayor Sigfrido M. Plessel. There was absolutely no collaboration by the different staffs. This procedure was later strongly criticized by Argentine military officers. They also said that there was excessive secrecy involved (Cervo 45).

${ }_{84}^{83}$ Cardoso et al. 1983, 40.

${ }^{84}$ Freedman and Gamba-Stonehause 23.

${ }^{85}$ Cardoso et al. 1983, 48. 
${ }^{86}$ Levy and Vieliki 22.

${ }^{87}$ Freedman and Gamba-Stonehouse 27-28.

${ }^{88}$ From Sunday, March 7th to Tuesday, March 9th.

${ }^{89}$ Cardoso et al. 1987, 48.

${ }^{90}$ The specific details of this operation are not clear yet. For some observers it was part of an Argentine operative code named "Alpha." Others maintain that it was purdy coincidence that the incident happened then. The scrapping operation was a legal activity authorized by the British government.

${ }_{92}$ Aguiar 19.

${ }^{92}$ Lebow 1985, 110.

${ }^{93}$ Freedman and Gamba-Stonehouse 83. Only the appointed future governor of the Malvinas Islands, General Mario Benjamın Menéndez, expressed some concern about the success of the enterprise. Galtieri's answer to him was direct and abrupt: "The issue was thoroughly studied by the Junta and the foreign minister. You have to keep thinking on being military governor." (Cardoso et al. 1983, 64-68; my translation).

${ }^{94}$ Fontana 139.

${ }^{95}$ Cardoso et al. 1983, 88; my translation.

${ }_{97}^{96}$ Freedman and Gamba-Stonehouse 94-96.

${ }^{97}$ idem. 96.

${ }^{98}$ Given the way the Argentines had devdoped their strategy, this opportunity did not allow the Americans to act as early as during the Beagle emergency.

${ }^{99}$ Cardoso et al. 1983, 96.

${ }^{100}$ idem 103-04; my translation.

${ }^{101}$ idem 97-98.

${ }^{102}$ Cardoso et al. 1987, 85-86.

${ }^{103}$ David Lewis Feldman, "The United States Role in the Malvinas Crisis, 1982: Misguidance and Misperception in Argentina's Decision to Go to War," Joumal of Interamerican Studies and World Affairs 27:2 (1985). See also, Philip Windsor, "Diplomatic Dimensions of the Falklands Crisis," Millennium 12:1 (1983) $88-96$.

${ }^{104}$ Feldman 1985, 17.

${ }^{105}$ This opinion is also held by all the later literature on the Malvinas. Even Levy and Vakili assert that "the decision [to occupy the islands] was based on the confident assumption that the United States would either side with Argentina diplomatically or at a minimum stay neutral" (27). There is no doubt that after Reagan's phone call that the United States would not last very long as neutral.

${ }^{06}$ Lebow defines the situation to the Argentines as "they came increasingly to believe, and not without reason, that they were behaving like the proverbial donkey, tricked into pulling the cart by a carrot on a stick dangled before him" $(1985,104)$.

${ }^{107}$ Lebow 1985, 120. His epitaph echoed the words of one Argentine editor who commented: "Galtieri and the generals are cornered. They have nowhere to go but forward. If they go backwards, they will be swept away." For this reason, they "stayed locked into their suicidal collision course with Britain until the very bitter end" (1985, 121)

${ }^{108}$ Another issue that needs further elaboration is the line of research suggested by Carlos Escudé: How it was possible that the leaders and the society of a country like Argentina, characterized as dependent, vulnerable and essentially irrdevant to the vital interests of the great powers, thought that they could challenge those powers without paying any cost (Escude 1990 and Carlos Escude, Realismo Periferico. Fundamentos para la nueva politica exterior argentina [Buenos Aires: Planeta, 1992]).

${ }^{109}$ A similar recent case of initiating a fight against a more powerful enemy, although for different circumstances, is the war between Egypt and Israel in 1973. In that case, Egyptian leaders decided to resort to force "despite their adverse estimate of the general military balance" (Stein 1985, 58; see also 37 and 47).

${ }^{110}$ Lebow 1985, 122.

${ }^{111}$ idem. 97. 
${ }^{112}$ Lebow 1981, 222.

\section{REFERENCE LIST}

Aguiar, Félix Roberto. (1985). "La crisis y la guerra." In, Aguiar, F. R. et al. Operaciones terrestres en las Islas Malvinas. Buenos Aires: Circulo Militar. 13-41.

Amuchastegui Astrada, Armando. (1980). Argentina-Chile. Controversia y mediacion. Buenos Aires: Imprenta de los Buenos Ayres.

Cardoso, O. R., R. Kirschbaum, E. Van Der Kooy. (1983). Malvinas. La trama secreta. Buenos Aires: Sudamericana/Planeta.

-------. (1987). Falklands- The Secret Plot. S,urrey, UK: Preston Editions.

Cervo, Francisco. (1985). "Los factores historicos y geograficos." In F. R. Aguiar, et al. Operaciones terrestres en las Islas Malvinas. Curculo Militar. Buenos Aires. 63-86.

Child, Jack. (1985). Geopolitics and Conflict in South America. Quarrels Among Neighbors. New York: Praeger.

"Como se evito la guerra con Chile." Buenos Aires: Cların, August 19, 1984. 10-11.

Escudé, Carlos. (1990). El fracaso del proyecto argentino. Educacion e ideologia. Buenos Aires: Editorial Tesis/Instituto Di Tella.

(1992). Realismo Periférico. Fundamentos para la nueva politica exterior argentina. Buenos Aires: Planeta.

Feldman, David Lewis. (1985). "The United Sates Role in the Malvinas Crisis, 1982: Misguidance and Misperception in Argentinas's Decision to Go to War." Journal of Interamerican Studies and World Affairs 27: 2. 1-22.

Floria, Carlos y César Garcıa Belsunce. (1989). Historia politica de la Argentina contemporánea. 1880-1983. Buenos Aires: Alianza Universidad.

Fontana, Andrés. (1987). Political Decision Making by a Military Corporation: Argentina 1976-1983. Ph.D. dissertation. University of Texas at Austin.

Freedman, Lawrence and Virginia Gamba-Stonehouse. (1991). Signals of War. The Falklands Conflict of 1982. Princeton, New Jersey: Princeton University Press.

Garrett, James L. (1985). "The Beagle Channel Dispute: Confrontation and

Negotiation in the Southern Cone." Journal of Interamerican Studies and World 
Affairs 27: 3. 81-109.

Hastings, Max and Simon Jenkins. (1983). The Battle for the Falklands. London: Michael Joseph.

Janis, Irving L. (1982). Groupthink.sychological Studies of Policy Decisions and , Fiascoes. 2d ed. Boston: Houghton Mifflin Company.

Lanus, Juan A. (1984). De Chapultepec al Beagle. Politica exterior Argentina: 1945-1980. Buenos Aires: Emece.

Lebow, Richard Ned. (1981). Between Peace and War. The Nature of International Crisis. Baltimore: The John Hopkins University Press.

--1985). "Miscalculation in the South Atlantic: The Origins of the Falklands War." In Robert Jervis et al. (eds.) Psychology \& Deterrence. Baltimore: The John Hopkins University Press. 89-124.

Levy, Jack S. and Lily Vakili. (1991). "Diversionary Action By Authoritarian Regimes: Argentina in The Falklands/Malvinas Case." In M. I. Midlarsky (ed.) The Internationalization of Communal Strife (forthcoming).

Middlebrook, Martin. (1989). The Fight for the 'Malvinas.' The Argentine Forces in the Falklands War. London: Penguin Books.

Princen, Thomas Edward. (1988). Intermediary Intervention: A Model of Intervention and a Study of the Beagle Channel Case. Ph.D. thesis. Harvard University.

Russell, Roberto. (1990). "El proceso de toma de decisiones en la politica exterior argentina (1976-1989)." In Roberto Russell (ed.) Politica Exterior y Toma de Decisiones en America Latina. Buenos Aires: GEL. 13-59.

SIPRI Yearbook. (1982). "Militarization and Arms Control in Latin America." In World Armaments and Disarmament. New York. 406-411.

------.(1983). "The Falklands/Malvinas conflict-a spur to arms build-ups." In World Armaments and Disarmament. New York. 467-495.

Snyder, Glenn and Paul Diesing. (1977). Conflict Among Nations: Bargaining, Decision Making, and System Structure in International Crises. Princeton, N.J.: Princeton University Press.

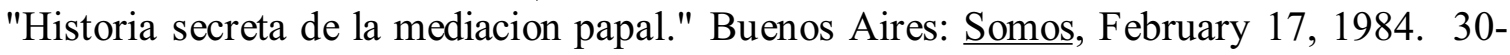
37.

"Historia secreta de la guerra que evito el papa." Buenos Aires: Somos, April 3, 1987. 2834.

Stein, Janice Gross. (1985). "Calculation, Miscalculation, and Conventional Deterrence I: The View from Cairo." In Robert Jervis et al. Psychology \& Deterrence. Baltimore: The John Hopkyns University Press. 34-59.

Tetlock, Philip. (1983). "Psychological Research on Foreign Policy. A methodological overview." In L. Wheeler and P. Shaver (eds.) Review of Personality and Social Psychology Vol. 4. Beverly Hill: Sage Publications. 45-78.

Wainstein, Leonard. (1985). "Reflexion on a Small War." Conflict 6:2. 97-115.

Wilhelmy, Manfred. (1990). "Las decisiones de politica exterior en, Chile." In Roberto Russell (ed.) Politica exterior y toma de decisiones en America Latina. Buenos 
Aires: GEL. 135-164.

Windsor, Philip. (1983). "Diplomatic Dimensions of the Falklands Crisis." Millennium 12: $1.88-96$. 